\title{
CELEBRATING QUEER LESBIAN DESIRES WITH DOROTHY ALLISON: FROM MORAL MONSTROSITY TO THE BEAUTIFUL MATERIALITY OF THE BODY
}

\author{
Mélanie Grué \\ Université Paris-Est Créteil \\ Paris, FR
}

\begin{abstract}
Using social and queer theory on domination, sexuality and gender, this contribution explores how the queer American author Dorothy Allison celebrates the vilified transgressive lesbian body. As, in the 1970s, the mainstream American feminist movement crystallized around the definition of an acceptable sexuality in the name of femininity, female sexual practices were standardized according to strict identity frames, carnal desire was denied, and transgressive lesbians who play with gender roles were defined as abject. In response to this extreme taming of the body, Allison interrogates the notions of masculinity and femininity, domination and submission in her exploration of sexual pleasure and traumatized sexuality. She celebrates the aggressiveness and masculinity of queer lesbianism, promotes the fluidity of gender roles, and asserts the primacy of the flesh, sensuality, and materiality in sexuality.
\end{abstract}

Keywords: Dorothy Allison; feminism; gender; lesbian body; sexuality.

\section{Introduction}

According to Judith Butler, sexual identity is not freely chosen, the individual's choices being constrained by social regulations and heteronormativity (Bodies 95). Thus the formation, circulation and signification of bodies are mobilized by the law, which is reproduced by a seemingly free subject in a process that Butler calls "performativity." She envisions sex as a regulated production which contributes to the definition of viable bodies and to the preservation of the social order: the reiterated performance of sexual identity, which comes with constraints and a threat of ostracism or death to those who do not comply with the rules, becomes instrumental in perpetuating acceptable sexual practices (23; 95). In Gender Trouble, Butler asks: "how do presumptions about normative gender and sexuality determine in advance what will qualify as the 'human' and the 'livable'? In other words, how do normative gender presumptions work to delimit the very field of description that we have for the human?" (xxiii). Concepts of sex, sexuality and gender underlie the definition of a viable and intelligible identity, so much so that practices which do not conform to gender norms interrogate the very notion of "person" (23). Besides, Sara Ahmed explains that the principle of "compulsory heterosexuality [...] shapes what it is possible for bodies to do [...]. Bodies take the shape of norms that are repeated over time and with force" (Cultural Politics 145). The attraction or repulsion of a body by another defines the value granted to pleasure, in the sense that pleasure is considered valuable only if the body is attracted to a body of a different sex. In virtue of the prohibitions and injunctions aiming at guaranteeing a certain social order, homosexuality was first defined as an abject position, to be repudiated in the favor of heterosexual identification (163). If homosexuality came to be increasingly acceptable,

\footnotetext{
${ }^{*}$ Mélanie Grué, $\mathrm{PhD}$, is a temporary teaching and research fellow at Université Paris-Est Créteil Val-de-Marne, where she teaches Literature, translation and English for specialists of other disciplines. Her fields of research include Dorothy Allison's works, trauma and resistance literature, literary representations of the body and sexuality, gender and queer studies, as well as feminist and queer visual arts. E-mail: melanie.grue@hotmail.com.
} 
social regulations and prohibitions evolved and new abject identities emerged, along with the definition of new aberrant bodies and practices.

Indeed, history proved that the liberation movements themselves are not immune to the temptation to define unbearable positions. The anxiety provoked by non-viable sexual practices has never stopped feeding and orienting the claims of the feminist and gay liberation movements: as the first victories were won against the stigmatizing definition of homosexuality, priorities and goals shifted within increasingly moralized groups acting along strict lines of identity definition. In the 1970s-1980s, while still fighting against male violence, mainstream feminism and lesbian-feminism hardened their speech and made female sexuality a key element in the struggle against inferiority. A new, morally acceptable feminist sexuality was defined, from which humiliation, power relations and violence were excluded. The reality of the corporeal experience was ignored, the diversity of female sexualities was disregarded, and the question of pleasure and desire seemed to become dangerous. Consequently, transgressive sexualities based on gender roles and violence were excluded from the sphere of acceptability, deemed immoral and anti-feminist.

An incest survivor and sadomasochist lesbian feminist, the American writer Dorothy Allison found herself in the middle of the lesbian-feminist debates over the correct expressions of female sexuality. In her political writing, she addresses the question of pleasure and desire, takes part in the feminist conversation on the status of women, and calls for more openness, tolerance and honesty, arguing that women will not be free unless desire enters the public realm. This article proposes to explore how Allison's representation of the female body contributes to make desire and pleasure public, and opposes the abstract, sterilized female figures promoted by the moralized liberation movements. It will first explain the modalities of the "Sex Wars" which tore the feminist movement apart in the 1970s-1980s, and the consequent creation of morally and physically monstrous female figures. An analysis of Allison's depiction of intimate relations will show that genders are subverted and trauma is overcome by transgressive lesbian bodies which question the value of femininity. Finally, we shall see that against feminist abstractions, Allison's writing of the flesh glorifies the desires and needs of the material female body.

\section{Moralizing sexuality, shaming the monstrous lesbian body}

In a patriarchal society where sexuality is constructed in order to satisfy the dominant group's political interests, women are transformed into passive objects of male pleasure and submitted to the norms and restrictions it implies (De Lauretis 62). When it was created, the American feminist movement thus reasserted women's right to control their bodies and sexuality, and fought against male domination and oppression. The gay liberation movement, as for it, intended to overthrow heterosexist social structures based on gender asymmetry and the nuclear patriarchal family. Gay liberationists contended that homosexuality announced the subversion of normative categories of sex and gender (Jagose 3637). However, the feminist and gay movements progressively crystallized around acceptable definitions of homosexuality or femininity, started to defend hegemonic values, and excluded from their ranks those who did not satisfy them. Some gays and lesbians became representatives of normality, while others were considered deviant and were marginalized (Hollibaugh 264), leading Matt Wolf to observe:

[A]re we now too mainstream, too visible and acceptable, to desire a kind of sexual liberation that renders our sexuality countercultural and radical? If mainstream gay politics, specifically the politics of gay marriage, neutralize and soften the edge of gay sexuality, then is a call for liberated, utopic, and radical intergenerational sexuality in fact a nostalgic impulse that clings to previous ideals and modes of expression? (668)

As she studies the evolution and hardening of the gay liberation movement, Jagose remarks that the homosexual community progressively constructed itself as an ethnic minority with recognizable characteristics 
and a clearly defined identity, in order to legitimize its claims and defend its rights within a preexisting social structure (61). Similarly, Steven Seidman deplored the mainstreaming of a movement which, he noticed, was no longer as demanding as it was when it first formulated claims for recognition ("Symposium" 172). As it evolved along the ethnic model, the gay and lesbian movement defined a fixed homosexual identity, characterized by monogamous, intra-racial, intra-generational romantic relations and reinforcing itself through the exclusion of certain practices, such as butch/femme couples interracial relations and sadomasochism, the latter being considered "deviant, abnormal, or perverse" (Seidman, Difference 149-150; 201).

Within the feminist movement, the debates over sexual identity culminated in what came to be known as the "Sex Wars," which had a significant impact on lesbian-feminist circles. Indeed, from the mid-1970s the movement progressively abandoned its initial claims (the right to abortion and contraception, and the struggle against domestic violence) and engaged in an agitated reflection on sexual practices and the representation of women (Freedman and Thorne 103). The antipornography movement developed in parallel to previous discourses on rape and physical violence, and became a strong branch of the struggle against male violence and the humiliating sexuality associated with it (Echols 4547). When pornography was targeted as a violent mode of representation perpetuating violence against women, a sterile debate started between the moral purists and the pro-sex feminists. Its aim was to decide whether sadomasochism, pornography and "transgressive" sexualities were to be considered as liberating alternatives to the humiliating patriarchal sexuality or as proofs that women internalized their inferior position and participated in their own oppression.

As a new definition of an acceptable feminist identity emerged, desires, pleasures, fantasies, and the materiality of the body were forgotten. The feminist struggle hardened its fight against male domination, non-normative sexual practices were vilified, the body's eroticism was controlled, and any connection of the female body with brutality, humiliation and oppression was severed. Any form of sexuality turning power relations into erotic role games was morally condemned, which particularly affected the lesbian circles. For example, the National Organization for Women's 1980 resolution defined "tolerable feminist expressions," and explicitly opposed the inclusion of pornography and sadomasochism in lesbian claims (Hart 83). Lynda Hart remarks that the resolution's terms imposed to the lesbians willing to join the NOW a certain lifestyle, based on the static and de-eroticized identity of the lesbian (85). Respect, romanticism and equality became key notions in the definition of collectively decided sexual practices.

Seidman describes the dangerous moral line which divided the movement and led to further exclusions: "rigid moral boundaries crystallize, that classify sexual desires and acts into 'normal' and 'abnormal', and categorize them as good, healthy and right versus bad, sick and wrong" (Embattled 188189). Consequently, the body became the bearer of an abject, morally twisted lesbian subject, and the marker of deviance. The body itself is envisioned as a threat, as transgressive sexual practices might spoil the healthy core of the liberation movement. The divisions are complex, yet a clear opposition developed from the late 1960s between "radical" and "libertarian" feminists. Radical feminists condemn any practice implying the "male" ideology, and instead promote intimacy, tenderness and affection (Sawicki 29-30); libertarians promote the transgression of sexual norms and the liberation of sexual practices, as exemplified by Ann Ferguson's assertion that "[as] feminists we should reclaim control over female sexuality by demanding the right to practice whatever gives us pleasure and satisfaction" (109). Reflecting upon the radicals' conception of sexuality and intimate relations, Seidman remarks that sexual relations oriented towards the body, motivated by carnal desire, and implying role games are considered as masculine (Difference 126); he hereby formulates the distortion of perception of the female body implied by the moral stance taken by feminism. The transgressive lesbian body becomes monstrous, a combination of female attributes and male behavior, an uncanny mix of femininity and masculine aggressiveness, 
which justifies marginalization and stigmatization. Thus, as Judith Butler feared, the feminist movement idealized certain expressions of gender and set up new hierarchies (Gender viii).

As a pro-pornography, masochist lesbian feminist giving into gender roles, Allison was quickly targeted as a problematic member of the lesbian-feminist movement. She defines herself as queer, meaning that she is a transgressive, masochistic, sexually aggressive, pornographic lesbian, and an adept of butch/femme roles and leather feminism ("Question" 23-24). She remarks that the feminist and homosexual claims of the 1980s-1990s led to the forgetting of the body, the rejection of desires and the silencing of an important section of lesbian-feminism. Considered as immoral, the pro-sex lesbians were rejected in a sphere of otherness in the name of morality, and Allison explains that she was driven out of the feminist community because of her "sexual promiscuity, butch/femme orientation, and exploration of sadomasochistic sex" (34). Lesbian-feminists, whose sexual practices were said to promote patriarchal, macho discourses, were marginalized, which is unbearable for Allison, who writes: "it was a miracle I did not kill myself out of sheer despair when I was told I was too lesbian for feminism, too reformist for radical feminism, too sexually perverse for respectable lesbianism" ("Survival" 215). She deplores the fact that feminism erected rigid frames and defined an appropriate woman with decent desires in order to legitimize its position in the political field: indeed, as she reflects upon the workings of the social structure with regards to identity claims, she remarks how lesbian-feminism identified more closely with heterosexuality and heterosexual practices, in order to gain respectability and score points:

[W]e have pandered to this sex-hating, sexfearing society by pretending, as lesbians, that we are really no different from heterosexuals; and by placing such a strong emphasis on statistics that portray lesbians as monogamous, couple-and community-centered, and so much more acceptable than those publicly provocative, outrageous, and promiscuous queers. ("Public Silence" 118)
Allison explains that she "liked the theory of the womanidentified woman, liked watching women make other women the priority in organizing for civil rights, liked that even heterosexual women were beginning to see, on a day-to-day level, that treating other women badly was no longer socially acceptable." However, those she calls the "political lesbians," it seems, bended the definition of lesbianism in order to make it decent, so that they "made the concepts of lust, sexual need, and passionate desire more and more detached from the definition of lesbian" ("Conceptual" 139-140). Hence, although Jagose remarks that lesbian sexuality was first theorized as an alternative to oppressive male sexuality and defined as the quintessential feminist, equalitarian sexuality (64), it appears that as time went by only some lesbian expressions were tolerated, at the expense of any sexual practice making the body a complex centre of eroticism.

Allison describes in her poems the gap that widened between her and other women due to their diverging conceptions of sexuality:
God on their right shoulder righteousness on their left, the women who hate me never use words like hate speak instead of nature of the spirit not housed in the flesh as if my body, a temple of sin, didn't mirror their own ("The Women" 23).

We find here an illustration of the setting up of a sexual and corporeal norm aiming at standardizing practices. The hatred directed towards Allison is very explicitly linked to her sexual practices; the religious notions of deviance and sin strictly separate decent sexual practices from immoral tendencies. Morality and sin are inscribed on the body and the flesh, and the division among women is translated into the image of the bodies which fail to mirror one another. Allison draws a list of the characteristics which moral purists despise:

\section{Whitetrash \\ no-count \\ bastard \\ mean-eyed}


garbage-mouth

cuntsucker

cuntsucker (23).

The poem is transformed into a list as Allison enumerates the insults addressed to her. Sexual orientation and class mingle in the moral purists' demeaning of the poor white lesbian, illustrating Vance and Barr Snitow's assertion that although the first dissensions within the feminist movement were linked to the bad reputation of lesbianism, more recently class, religion, ethnicity and race led to new divisions (134). "Cuntsucker" is repeated twice, suggesting that the problem lies in sexual practices and the place granted to the body. Allison then addresses the surprising reason why the women insult her:

\author{
The women who hate me hate \\ their insistent desires, their fat lusts \\ swallowed and hidden, \\ disciplined to nothing \\ narrowed to bone and dry hot dreams. \\ The women who hate me deny hunger and \\ appetite, \\ the cream delight \\ of a scream \\ that arches the thighs and fills \\ the mouth with singing (24).
}

Corporeality persists despite the attempt at abstracting sexuality: "insistent desires" and "fat lusts" convey the unease felt by the most moral feminists as they have to face the demands of their bodies, which are violently "swallowed and hidden, disciplined to nothing," an enumeration hammering the idea of the endless repression of appetites while pointing to the hypocrisy of those who forge their morality by ignoring the sexual tendencies which are common to all. Repression here translates into images of hardness, rigidity and dryness through the mention of bone and dry hot dreams, which convey the harsh control imposed on a body haunting the female subject at night. Opposite the forced draining of the female body, Allison places the richness, thickness and suppleness of the comfortable body, which relates to hunger and repletion ("hunger and appetite"; "cream delight"; "fills the mouth") and is loudly and happily alive, as the singing suggests. The poem thus contrasts imposed silence and discipline with liberating lust and voicing, as the body arches and screams, free of all constraints.

Allison asserts that the divisions tearing the feminist movement apart will not disappear unless women face the question of desire and their fear of abnormality. She illustrates her argument by relating a conversation she had with one of her lovers concerning the definition of "feminist" sexuality. As she recounts her lover's words and reaction as she "slid down [her] lover's sweaty belly to mush [her] face between her thighs," she makes clear how acceptability matters and how the definition of lesbian sexuality is left to other people:

\begin{abstract}
"I hate that," she had hissed at me. "That's what they think we do." Her they was piercing and contemptuous, evoking every man who had jerked off to the image of dykes licking hungrily at rigid clits. Hurt and frustrated, I had argued that I was no man and I wanted to do it. [...] No one admitted using dildos, wanting to be tied up, wanting to be penetrated, or talking dirtyall that male stuff. Sex was important, serious, a battleground. My lover wanted us to perform tribadism, stare into each other's eyes, and orgasm simultaneously. Egalitarian, female, feminist, revolutionary. ("Sex Writing” 87)
\end{abstract}

The problem, it seems, is that there is nothing revolutionary in yielding to others and giving them the right to define how you are going to live in your own body. Here again, the problem lies in "male stuff" and in how masculinity comes to define the female body and female practices deemed unacceptable and rejected in favor of tender relations based on a controlled, tamed body which ignores his own cravings. Desire is scary. It is diverse, unforeseeable, and resists any attempt at definition. It is thus moralized and silenced, rather than explored and shared ("Puritans" 95). In "Bertha Harris, a Memoir," Allison explains the disastrous consequences of this attempt at walling up desire: "The fear of being monstrous, alone, and denied would dog us all, destroy some of us, and bend that culture we all dreamed about into shapes we could not then imagine" (205). The moralization of the feminist movement thus led to the standardizing of practices and to the denaturalization 
of the lesbian body, as lesbians were taught to despise themselves and to conform to the smooth practices promising to ensure the movement's respectability.

\section{Acknowledging queer desires, questioning genders}

In her study of queer, Jagose explains that it "describes those gestures or analytical models which dramatise incoherencies in the allegedly stable relations between chromosomal sex, gender and sexual desire. [...] queer focuses on mismatches between sex, gender and desire" (3). Seidman draws a succinct history of the queer movement and explains that western homophobic theory and affirmative homosexual theory are constructed around the clearly defined and delimitated figure of the homosexual, while queer theorists assert that identities consist in an ever-renewed combination of various components, among which sexual orientation, race, class or gender (Difference 92). They oppose fixed, arbitrary, reductive identity constructions, whose definitions fail to encompass all identity experiences, and which thus become disciplinary structures (93). Queer has thus become the rallying cry for vilified identities: sadomasochists, butches, femmes, perverts and other individuals rejected by the moralized liberation movements found in queer the opportunity to claim the value of their conceptions of sexuality and pleasure (93). Juana Maria Rodriguez explains that through sexual encounters, "queers enact the possibility of disentangling bodies and acts from preassigned meanings, of creating meaning and pleasure anew from the recycled scraps of dominant cultures" (338). Rodriguez places eroticization and pleasure at the core of a process through which queers go against stigmatization and marginalization (338).

In the light of these definitions, it appears that the feminist and homosexual movements evolved in opposition to the queer ideal of subversion and liberation, by limiting sexual possibilities and condemning non-normative behaviors. As the liberation movements assigned new meanings to sexed and gendered bodies, they re-created a dominant, oppressive culture which stigmatized and marginalized figures of difference. As Dorothy Allison understood the complex workings of the moralized feminist movement, she asserted her belief in the power of desire and the need to acknowledge it, thus formulating an undeniably queer conception of the body and calling for the free exploration of sexuality. Her long poem on the various relationships she has had with women over the years ends with the formulation of her implicit wish that divisions stop and women unite without denying themselves:
Where then will I find the country where women never wrong women where we will sit knee to knee finally listening to the whole naked truth of our lives? (“The Women” 31).

She describes how genders can be rethought and reconfigured in sexual relationships; she interrogates the validity of such notions as masculinity and femininity, morality and decency, through her celebration of beautiful lesbian subjects and her depiction of the material body. She asserts:

\begin{abstract}
I believe that sexual desire is a powerful emotion and a healthy one. I'm pretty sure that when anyone acknowledges and acts on their desire, it does us all some good-even if only by giving other people permission to act on their desirethat it is sexual repression that warps desire and hurts people. ("Conceptual" 142)
\end{abstract}

If the moralized movements failed in their attempt at liberation, the queer project struggled in favor of the acknowledgement of so-called deviances and the proliferation of gender roles. Gayle Rubin explains that sadomasochism, rather than being a form of humiliating violence, is a ritualized sexual game practiced by responsible, consenting people (283). Barbara Dority notes that sadomasochism does not aim at degrading individuals or promoting violence, but at finding pleasure in domination, submission and controlled pain. In her defense of vilified practices, Amber Hollibaugh explicitly raises the question of identity, suggesting 
that the struggle against pornography creates "new definitions of sexual sickness and deviance"; she draws a list of all the vilified identifications and attitudes, thus implicitly asserting the worth of marginalized lesbians:

Who are all the women who don't come gently and don't want to; don't know yet what they like but intend to find out; are the lovers of butch or femme women; who like fucking with men; practice consensual S/M ; feel more like faggots than dykes; love dildos, penetration, costumes; like to sweat, talk dirty, see expressions of need sweep across their lovers' faces ; are confused and need to experiment with their own tentative ideas of passion; think gay male porn is hot; are into power? (95-96)

The definition of a "feminist" sexuality based on respect, consent and equality helps us understand the feminist disagreements over the butch/femme couple, the detractors of which consider that it perpetuates the male-centered vision of the social structure which, Bourdieu says, turns the sexual act into a relation of domination between the masculine and the feminine (37). According to Bourdieu, sexual intercourse is constructed through the fundamental principle of division between the active masculine and the passive feminine. This dividing principle creates masculine desire as a desire for possession and as eroticized domination, while feminine desire becomes eroticized subordination and acknowledgement of domination (37). Hollibaugh, on the contrary, considers that a blooming feminine sexuality may be based on aggressiveness and a certain form of masculinity: she positively considers the mingling of genders noticeable in transgressive lesbianism, and finds value in a destabilizing female body which relinquishes a share of femininity in order to endorse the power traditionally granted to male bodies.

Similarly, Allison precisely describes the sexual acts which give her pleasure because they blur the frontiers between genders. For example, she describes how she discovered the possible uses of the dildo with one of her butch partners:
... then something cold and rubbery pressed against my legs.

I held still. I had an idea what that was and I wasn't sure I liked it. [...] I wiggled again, thinking about stopping her. Maybe we could discuss this?

But Marty had no intention of stopping to discuss the politics of using a male-identified sexual apparatus. Her rubbery appendage ground enthusiastically at my labia while her other hand and her mouth worked fiercely to get my full attention ("Theory and Practice" 129).

The masculine act of penetration is accepted and fascinating, which was still a dissident point of view at the end of the 1970s. Allison, however, enounces the paradox that pertains to the use of dildos, as she reveals that although they are widely deemed masculine and insulting to women and femininity, they are very much used, and not only by butch/femme couples or $\mathrm{s} / \mathrm{m}$ women. She explains: "With the wider discussions of sexual behavior in the lesbian community in the past few years, more women have been coming out about their enjoyment of penetration and penetration devices" ("The Theory and Practice" 132-133), which reveals not only an unexpectedly vast range of practices, but also the unease that hits women regarding their corporeal experiences. Allison stands against the general unease when, in her first novel Bastard Out of Carolina, the abused girl Bone finds comfort and assurance of her self-worth when she rediscovers sexuality in the safety of her room, using a metal chain, a lock and a hook in order to fasten herself and masturbate. In the episode when Bone uses these sexual accessories in the dark, Allison makes her point about sexuality and the female body: the abused girl is submitted to daily physical violence and frequent sexual abuse, yet discovers sexual pleasure and an unexpected relief when she uses male-connoted objects on her own terms. In a disturbing sadomasochistic scene, Bone uses the metal chain as a harness and the trailing hook found in the river (and usually used to dig cars and dead bodies up to the surface) as a makeshift dildo. In the darkness of her room, the girl regains control over herself and unashamedly discovers the pleasure attainable in a body which does not forget itself and is submitted to no external force: 
I used the lock I had found on the river bank to fasten the chain around my hips. [...] I had read in one of the paperbacks Daddy Glen hid in the garage about women who pushed stuff up inside them. I held the chain and thought about that [...] I wasn't like the women in those books, but it felt good to hold that metal, to let those links slip back and forth until they were slippery. (193)

Bone reinvents the heterosexual act, relieving it of any tint of coercion and revisiting power relations in a solitary act thanks to which she can occupy all the positions on the spectrum of authority. The incest victim's sexual game forcefully suggests the possibility to bloom in a sexuality tinted with violence and danger, provided the participant is free to exert control on her body as the sexual act unfolds.

Associated with this blurring of the masculine and the feminine is Allison's social background. Born and raised in a poor white family in South Carolina, Allison makes class an essential component of her sexual identity. As she asserts that her sexuality is shaped both by class and sexual abuse, she once again contradicts the mainstream feminist opposition between male violence and female innocence: her depiction of female bodies questions the binary division between male masculinity and female femininity, and reveals that the body is situated at the crossroads of genders, bearing the marks of race and class. The sensual materiality of texts which eroticize the skin and the bodies places the reader in front of the reality and complexity of a desire forged on a background of violence. Examining the links between the violence of childhood and her aggressive sexuality, Allison explains:

I knew the first time I made love with a woman that I could cry but I must not say why. I cried because she smelled like him, the memory of him, sweaty and urgent, and she must not know it was not her touch that made me cry. Breathing her in prompted in me both desire and hatred, and of the two feelings what I dared not think about was the desire. Sex with her became a part of throwing him off me, making peace with the violence of my own desire. [...] how many times I sat up till dawn wondering if it would ever change, [...] If there would come a time in my life when desire did not resonate with fury. (Two or Three 48)

The link between abuse and sexuality is firmly established here, the one between victimization and innocence is broken, as Allison tells how she constructed herself on a basis of violence. Sexual desire is mingled to hatred and the crushing masculine violence of abuse, yet the female subject emerges from the text, presenting her body as the site for the terrible association of sexual pleasure with the fury of sexual violence. Allison makes clear that the abused woman's relation to her body is not as simple as feminism would have the world believe. The body cannot be easily forgotten and sexual relations are not self-evident. The image of the abuser being thrown off her conveys the idea of a lasting marking of the body, which is only progressively freed from male mastery thanks to the momentary conflation of the female lover with the male abuser. Allison explains how sexuality first consists in a recovery of the body which was made alien and is rediscovered by the former victim:

I took my sex back, my body. I claimed myself
and remade my life. Only when I knew I
belonged to myself completely did I become
capable of giving myself to another, of finding
joy in desire, pleasure in our love, power in this
body no one else owns. [...] incest is a coat of
many colors, some of them not visible to the
human eye, but so vibrant, so powerful, people
looking at you wearing it see only the coat. I
did not want to wear that coat, to be told what
it meant, to be told how it had changed the
flesh beneath it, to let myself be made over into
my rapist's creation. I will not wear that coat,
not even if it is recut to a feminist pattern [...].
(Two or Three 70-71)

Against the conception of an exclusively male sexual power, Allison denounces the damage created by incest without yielding to the temptation to serve a certain discourse on gender relations. As she refuses to "wear the coat" of the innocent feminine victim, she questions reductive conceptions of feminist sexuality and contends with the question of traumatized sexuality. In her poems, she mixes love and abuse in a disturbing 
definition of transgressive sexuality. The trauma of childhood and the feeling of safety felt in the adult, consented relationship are barely distinguishable, and the tortured body is presented as irreversibly marked yet re-appropriated in the lesbian act.

In "We Make Love" (67) the sexual act is read as a game in which power relations between abuser and victim are reproduced, yet the repetition of the lines "we make love" (six times) and "it's a game" (eight times) plants seeds of doubt in the reader's understanding of the "game." The structure of the poem is intricate, thus mirroring the intricacy of the victim's sexual identity: lines describing sexual games point either to the victim's despair and her submission to an almighty abuser, or to her reclaiming power: "Maybe you'll live long enough"; "I know what you want/but I'm not gonna give it"; "Just what you deserve"; "Justice"; "Despair"; "The most vicious revenge"; "Reparations" all appear in italics in the poem where voices mingle, making it difficult to decide who of the abuser, the victim or the lover speaks the words. The poem ends on the double repetition "We make love/ We make love/it's a game/it's a game," followed by a new assertion which will not be repeated: "Even so/I come." This conclusion translates the awareness that pleasure and violence uneasily associate. The assertion might be tinted with guilt, or with amazement at the body's ability to find satisfaction in domination. The same ambiguity is found in "The Other Side of the Wall," in which two scenes are associated and compared: in the first one, the girl-narrator hears her mother and stepfather having sex through the thin walls separating their bedrooms; in the second scene, the adult-narrator is described during her own sexual intercourse with a lover. In the first scene, the sexual act is described in explicit images:

The other side of the wall they are making love my mama croons a deep-throated bird under wet leaves,

rides my stepfather's staggered engine roar. $[\ldots]$

every night, after the bath and the shouting

he takes her to bed, grounds her

to the wall where our fingers

press the mystery, the unseen

clearly heard train of desire (68).
The sexual act accomplished by the adult narrator and her female partner mirrors the first scene:

This side of the wall we are making love teeth, tongue, hands all entwined.

You ride hard the edge of my hip, swing me belly tight up to the flat of the wall.

I reach back, become a train gaining speed (69).

Again, repetition closely associates the abuser and the emancipated victim. Here, the mother and lover "ride" alike, the image of the train is used to describe both acts. Allison clearly interrogates gender roles and sexual positions when she more decidedly conflates the two scenes and observes: "I could, I swear to you, be my mama./You do, I swear, fuck like a man" (69). The narrator juxtaposes the two acts, merges the participants and associates her female lover to her childhood abuser. Lesbian sexuality, while being closely connected to abuse, is also what promises to free the incest survivor. Masculine violence acquires a new significance thanks to the parallel established between the two scenes. Butch/femme sexuality allows the narrator to reassert her freedom of choice and her emancipation.

In response to the feminist tendency to forget the materiality of the body and to define an abstract female and feminine sexual identity, Allison exhibits the queer female bodies she encounters. In her writing, the bodies come into contact and the women interrogate the notions of masculinity and femininity. Desire is celebrated as being ever-changing and not necessarily feminine; the incest survivor finds a disturbing comfort in sexual acts tinted with violence and with women whom she almost seems to mistake for her abuser. Sexuality is difficult, sexual identities fluctuate, and Allison's queer bodies refuse the fixity of the gender binary, revealing instead the many ways identity may be embodied.

\section{Writing the body, feeling the flesh, celebrating sexuality}

If Allison interrogates gender categories and reinserts class violence in her description of sexuality, she also celebrates the sheer materiality, thickness 
and fullness of the lesbian body. At times, flesh is all that matters to the narrative voices, who relish in the beauty of bodies and the richness of the senses. In these moments, the text itself is endowed with more density and abundance. In "Silence Grew Between Us," the various senses become prominent as the speaker describes the almost magical effect her lover has on her:

When you touched me my womb filled with light my mouth with light the deep places between my breasts flooded light full of the smell of baking eggplant, pure desire (32).

The metaphor of light powerfully conveys the feeling of satisfaction provoked by the love relationship, and elevates the lover to the rank of supernatural, fairy-like being providing beneficial light to those she touches. The speaker's own wonderment is expressed thanks to the extra space preceding "with light," as if a pause allowed her to think and find the appropriate words to describe such an unusual and satisfying process. The sense of touch is paramount, and the mention of the womb, mouth and breasts, body parts closely associated with sensual and sexual pleasure, anchor the poem in the sensory realm. Eroticism translates into the mingling of the senses and a near feeling of synesthesia, the light being perceived as "full of the smell/of baking eggplant." As Allison intertwines sex and cooking, repletion and sexual satisfaction, sexuality becomes as palpable and nourishing as the food it is associated with, undeniably good and detached from any notion of morality.

The same themes are developed in "What is the Dream of Flesh?" in which Allison expresses the necessity to go beyond mere fantasy and to engage in actual physical relationships. She once again associates flesh and food, putting forward the material body as the only satisfying place. Indeed, she bluntly asserts that "The dream of flesh is not enough" (53), before reaffirming the primacy of the body and the flesh:
Flesh on flesh sunlight on my eyelids I dream of the body the muscles that long to loosen the belly's cry for justice bean soup and quiet for the eating a breath that rises easy to the mouth (53).

Flesh seems to pile up as the speaker suggests a sharpening of the senses and sensations, and successively focuses on various parts of her own body: eyelids, muscles, belly and mouth are here again considered in relation to light, physical satisfaction and food. The reason for this constant return to the belly and to food is explained:

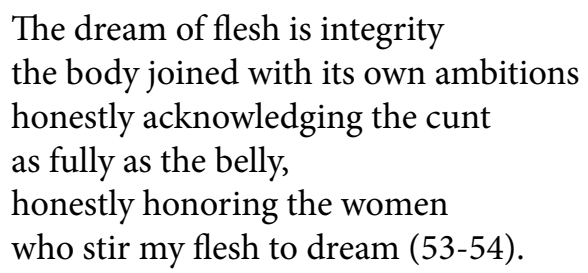

By devoting the poem to sexuality and nutrition, Allison de-dramatizes women's relation to their bodies and sexuality, while making clear that sexuality is as essential as food. By mentioning "integrity" and "the body joined with its own ambitions," she suggests that women who deny the reality of their sexual desires are incomplete, lacking and fragmented. Cunt and belly are leveled in these lines, the ignorance of sexual need being implicitly linked to starvation.

The woman who fully acknowledges herself, on the contrary, is full of life and strong, like the woman described in "A Woman Like an Ocean." As the speaker describes lovemaking, the poem reproduces the ebb and flow of the ocean to which the woman is compared:

Her hands rough as she rolls me over Talks mean, drags me forward and back, When she fucks like an ocean, a bruiser Makes shell-puckered hickey-bite marks, When she moves like she's breaking out thunder,

When she rises like spray in the wind. Singing roll over, roll over and ride me Roll over, swim down, laugh out loud (50). 
The water metaphor makes the roughness of lovemaking fluid and soft, and the harmonious distribution of actions in the lines of the poem reproduces the rolling movement of the bodies. The references to water and weather ("like an ocean, a bruiser"; "like she's breaking out thunder"; "like spray in the wind") turn the woman into a sublime figure, a goddess of the sea who has power over the natural elements. The act of love is tinted with violence, yet this particular sort of violence is linked to strength, determination and pride in one's body. It seems that the body is roughed up (" she rolls me over $[\ldots]$ drags me forward and back [...] Singing roll over, roll over and ride me/Roll over, swim down"), yet as the poem unfolds and each line adds a new rolling movement, the body also appears as flexible and settled in the regularity of the flow.

If Allison refuses to let the body starve for want of physical satisfaction, she also refuses to let the language of sex dry up. Through language she makes the bodies alive on the page, yet she sometimes turns away from poetic images in order to crudely describe the reality of sexual relations. When she was taking a writing class with Bertha Harris, the latter asked the group: "write for me about going down" (“Sex Writing” 86). Allison recalls:

I thought about all the pornography I had ever read. Male language. Fucking. I liked oral sex as an act of worship, after fucking strenuously, after coming and making her come. Afterward, teasing a clit so swollen my touch is almost agonizing, listening to her moan and weep above me, or performing that act of worship while her fist is twined in my hair, holding me painfully, demanding that I work at this thing, strain with every muscle in my body until my neck and back are burning with pain and I can barely go on, following her every movement, every gasping demand, coming myself as she comes, released from the torment, orgasming on the agony and the accomplishment. (87-88)

Compared to the descriptions provided in the poems, this section provokes quite a different feeling, as the readers' impression of direct witnessing is reinforced by the details given, which make them feel as if they were violating the couple's intimacy. The various stages of the sexual act are all very precisely rendered, and the text leaves almost nothing to imagination: "fucking strenuously"; "a clit so swollen"; "moan and weep above me"; "her fist is twined in my hair"; "holding me painfully"; "following her every movement"; "coming myself as she comes." The body is described in the most satisfying moment, the connection between the two women is complete and the text follows the transfiguration of the body, which tightens painfully only to loosen in orgasm. "Strain"; "burning with pain"; "released"; "agony and the accomplishment" all point to the physicality of sexuality and to the materiality of the lesbian subjects, who cannot be abstracted and made ethereal in honest discourses on sexuality.

Corporeal connections and the proximity of the flesh allow the partners to go beyond their class differences and their disagreements on sexuality, and the sense of touch is central to the conciliation of the partners and to the celebration of the undeniably female and sexualized body. In the short story "Her Thighs," Allison describes her sexual games with a lover very much attached to social distinction, who "believed lust was a trashy lower-class impulse, and she so wanted to be nothing like that" (119). Bobby becomes a representative of the moral purists who reject lust in a sphere of depravity associated with poverty, and strives to appear as a respectable woman: "she loved her chintz sofa, the antique armoire with the fold-down shelf she used for a desk, the carefully balanced display of appropriate liquors she never touched [...] Bobby loved the aura of acceptability, the possibility of finally being bourgeois, civilized, and respectable" (120). Accordingly, sexual relations are controlled and feel sterilized; Bobby leaves no room for the unexpected and the thrill it would provoke:

Early in our relationship, she established a pattern of having me over for the evening and strictly enforcing a rule against sex outside the bedroom. Bobby wanted dinner-preferably Greek or Chinese takeout-and at least two hours of television. Then there had to be a bath, bath powder and tooth brushing, though she knew I preferred her un-bathed and gritty, tasting of the tequila she sipped through dinner. I was not supposed to touch her until we entered the sanctuary of her bedroom, that 
bedroom lit only by the arc lamp in the alley outside. Only in that darkness could I bite and scratch and call her name. Only in the darkness would Bobby let herself open to passion. (120)

The narrator describes her own conception of sexuality, in a reflection which refuses all constraint: "what I truly wanted was her in a rage, under spotlights in a stadium, fucking to the cadence of a lesbian rock-androll band" (120). Allison relies strongly on the body when she explains the strategies used to break the ritual imposed by Bobby.

Keeping my hands on her, I stared at her thighs intently until she started that sawing motioncrossing and recrossing her legs. My impudence made her want to grab and shake me, but that, too, might have been sex, so she couldn't. Bobby shifted and cleared her throat and watched me while I kept my mouth open slightly and stared intently at the exact spot where I wanted to put my tongue. My eyes were full of moisture. I imagined touching the denim above her labia with my lips. I saw it so clearly; her taste and texture were full in my mouth. I got wet and wetter. Bobby kept shifting on the couch. I felt my cheeks dampen and heard myself making soft moaning noises-like a young child in great hunger. That strong, dark musk odor rose between us, the smell that comes up from my cunt when I am swollen and wet from my clit to my asshole. (121)

The weight of prohibition and restrictions transforms sexual desire into sheer fantasy. The effort of containment and the tension resulting from it are perceptible in the description of the changes happening in the body. Close attention is paid to touch, smell and taste, which anchor the narration in the body forgotten by certain feminists. Allison thus expresses the need to reintroduce desire in the public sphere:

... when I speak as a lesbian about my own struggles to understand and publicly acknowledge the full meaning of my love for women, straight women nod back at me. I have heard them reveal their own terrible secrets, their own impossible desires. For all of us, it is the public expression of desire that is embattled, any deviation from what we are supposed to want and be, how we are supposed to behave. The myth prevails that good girlseven modern, enlightened, liberal or radical varieties-don't really have such desires. ("Public Silence" 117)

Allison's reflection perfectly illustrates Carole S. Vance's analysis of the status of women, the body and sexual pleasure in Western cultures. Vance explains that even though sexual pleasure is now more available for women than it was in the nineteenth century, it is "still complicated and frightening in a culture that is deeply hostile to both women and sex" ("More Danger" xvi). According to her, the problem lies in the fact that society does not work in favor of women's sexual pleasure and is even hostile to the free expression of sexual desire, which prevents them from fully experiencing "autonomous desire" (xvi). She deplores the fact that pleasure is relegated to the guilty private sphere instead of being granted a place in the public sphere, because this contributes to the disempowerment of women and to the continuing lack of knowledge about women's true lives ("Pleasure" 7). Allison, as for her, wants sex and the body to become central not only to the lives of women, but to the wider discussion on intimacy. As she explains that being angry makes her horny, she writes: "It isn't sex I want when I am like this. It's the intimacy of their bodies, the inside of them, what they are afraid I might see if I look too close. I look too close. I write it all down. I intend that things shall be different in my lifetime, if not in theirs" ("Her Body" 125). Just as moral purists turn away from the body, Allison sticks close to it, transgresses the frontiers of intimacy and looks closely at others. This allows her to fully document the reality of the female body, considered monstrous and yet so beautiful.

\section{Conclusion}

Queer claims cannot be formulated separately from the body which hosts the female subject. In Allison's writing, bodies come into contact, rub against each other, taste, smell and touch one another. The author defies dominant conceptions by bluntly depicting bodies in intimacy, even when she acknowledges how 
outrageous it feels to speak freely about the body, desire and pleasure. Sexuality is considered as anchored in the materiality of the body, despite the moral feminist assertion of the contrary. Allison's celebration of lesbian identity takes shape within the bodies, the one she inhabits and those she loves. For the queer lesbian author, social recognition cannot be complete without the acknowledgement of the palpable reality of the body. Women will be on the road to full liberation only when their corporeality becomes an essential part of the debates on liberation, and when pleasure and desire are considered natural and healthy. Allison's bodies bear the marks of social identity; they subvert sterilized conceptions by sprawling page after page, either in poetic descriptions where the body becomes surreal and sublime, or in texts where corporeality is almost felt through the words. As the moralized liberations movements promoted a tamed female identity based on a volatile, ethereal female body, Allison turned to the materiality of the flesh in order to celebrate the vilified bodies of those who refuse to lie and disappear.

\section{Note}

1. Italics mine.

\section{References}

Ahmed, Sara. The Cultural Politics of Emotion. Edinburgh: Edinburgh UP, 2004. Print.

Allison, Dorothy. "A Question of Class.” Skin: Talking About Sex, Class \& Literature. Ithaca: Firebrand Books, 1994. 13-36. Print.

"A Woman Like an Ocean." The Women Who Hate Me: Poetry 1980-1990. New York: Firebrand Books, 1991. 49-50. Print.

. Bastard Out of Carolina. New York: Plume, 1993. Print.

"Bertha Harris, a Memoir." Skin: Talking About Sex, Class \& Literature. Ithaca: Firebrand Books, 1994. 201-208. Print.

"Conceptual Lesbianism." Skin: Talking About Sex, Class \& Literature. Ithaca: Firebrand Books, 1994. 135-142. Print.

"Her Body, Mine, and His." Skin: Talking About Sex, Class \& Literature. Ithaca: Firebrand Books, 1994. 121-126. Print.
"Her Thighs." Trash. New York: Plume, 2002. 119124. Print

"Public Silence, Private Terror." Skin: Talking About Sex, Class \& Literature. Ithaca: Firebrand Books, 1994. 101-120. Print.

"Puritans, Perverts, and Feminists." Skin: Talking About Sex, Class \& Literature. Ithaca: Firebrand Books, 1994. 93-100. Print.

"Sex Writing, the Importance and the Difficulty." Skin: Talking About Sex, Class \& Literature. Ithaca: Firebrand Books, 1994. 83-92. Print.

"Silence Grew Between Us." The Women Who Hate Me: Poetry 1980-1990. New York: Firebrand Books, 1991. 32. Print.

"Survival Is the Least of My Desires." Skin: Talking About Sex, Class \& Literature. Ithaca: Firebrand Books, 1994. 209-224. Print.

"The Other Side of the Wall" The Women Who Hate Me: Poetry 1980-1990. New York: Firebrand Books, 1991. 68-69. Print.

"The Theory and Practice of the Strap-on Dildo." Skin: Talking About Sex, Class \& Literature. Ithaca: Firebrand Books, 1994. 127-134. Print.

"The Women Who Hate Me." The Women Who Hate Me: Poetry 1980-1990. New York: Firebrand Books, 1991. 21-31. Print.

Two or Three Things I Know For Sure. New York: Plume, 1996. Print.

"We Make Love" The Women Who Hate Me: Poetry 1980-1990. New York: Firebrand Books, 1991. 67. Print.

"What is the Dream of Flesh?" The Women Who Hate Me: Poetry 1980-1990. New York: Firebrand Books, 1991. 53-54. Print.

Bourdieu, Pierre. La domination masculine. Paris: Seuil, 2002 ed. Print.

Butler, Judith. Bodies That Matter: On the Discursive Limits of "Sex." New York: Routledge, 1993. Print.

Gender Trouble: Feminism and the Subversion of Identity. New York: Routledge, 2007 ed. Print.

De Lauretis, Teresa. Théorie queer et cultures populaires, de Foucault à Cronenberg. Paris: La Dispute, 2007. Print.

Dority, Barbara. "Feminist Moralism, Pornography, and Censorship.” 25 May 2015. <http://privat.ub.uib.no/ bubsy/dority.htm>. Web.

Echols, Alice. "Cultural Feminism: Feminist Capitalism and the Anti-Pornography Movement." Social Text 7 (1983): 34-53. Print. 
Ferguson, Ann. "Sex War: the Debate between Radical and Libertarian Feminists." Signs 10. 1 (1984): 106112. Print.

Freedman, Estelle B. and Barrie Thorne. "Introduction to 'The Feminist Sexuality Debates." Signs 10.1 (1984): 102-105. Print.

Hart, Lynda. La performance sadomasochiste : Entre corps et chair. Trans. Annie Levy-Leneveu. Paris: EPEL, 2003. Print.

Hollibaugh, Amber. My Dangerous Desires: A Queer Girl Dreaming Her Way Home. Durham: Duke UP, 2000. Print.

Jagose, Annamarie. Queer Theory: An Introduction. New York: New York UP, 2010. Print.

Rodriguez, Juana Maria. "Queer Sociality and Other Sexual Fantasies." GLQ: A Journal of Lesbian and Gay Studies 17. 2-3 (2001): 331-348. Print.

Rubin, Gayle. Surveiller et jouir: Anthropologie politique du sexe. Trans. Flora Bolter et al. Paris: EPEL, 2010. Print.

Sawicki, Jana. Disciplining Foucault: Feminism, Power, and the Body. New York: Routledge, 1991. Print.

Seidman, Steven. Difference Troubles: Queering Social Theory and Sexual Politics. Cambridge: Cambridge UP, 1997. Print.

Embattled Eros: Sexual Politics and Ethics in Contemporary America. New York: Routledge, 1992. Print.

"Symposium: Queer theory/Sociology: A Dialogue." Sociological Theory 12.2 (1994): 166-177. Print.

Vance, Carole S. "Pleasure and Danger: Toward a Politics of Sexuality." Pleasure and Danger: Exploring Female Sexuality. Ed. Carole S. Vance. London: Pandora Press, 1992 ed. 1-27. Print.

. "More Danger, More Pleasure: A Decade after the Barnard Sexuality Conference." Pleasure and Danger: Exploring Female Sexuality. Ed. Carole S. Vance. London: Pandora Press, 1992 ed. xvi-xxxix. Print.

Vance, Carole S. and Ann Barr Snitow. "Toward a conversation about Sex in Feminism: A Modest Proposal." Signs 10. 1 (1984): 126-135. Print.

Wolf, Matt, and Marvin J. Taylor. "On Fandom and Smalltown Boys: A Dialogue." GLQ: A Journal of Lesbian and Gay Studies 10.4 (2008): 657-670. Print.

Recebido em: 08/06/2015 Aceito em: 03/08/2015 